Review: for Social History 45:1 (2020), 125-7.

\title{
Bristol from Below: Law, Authority and Protest in a Georgian City
}

Steve Poole and Nicholas Rogers, Woodbridge, Boydell Press, 2017, xii + 387pp.

£70, ISBN 978-1-78327-244-0

\section{Robert Poole}

In Bristol from Below two leading historians of popular protest join forces to create what they call 'the first urban history from below of the long eighteenth century' (4-5). Working 'at the interface of social and political history', the authors take in the whole range of protest from the Glorious Revolution of 16889 to the Great Reform Act of 1832, offering a sort of regional version of Adrian Randall's excellent Riotous Assemblies (OUP, 2006). Bristol, 'a city of spires and masts', is the ideal place for such a study: a corporate city and a major Atlantic seaport, embedded in a region teeming with unruly workers and rebels, and endowed with civic, legal and naval archives as well as an early-developing newspaper press. It is a heroic work of recovery and reconstruction, but with its thematic chapters it also makes a useful book of readings for students.

The book falls into three parts. Chapters 1-3 offer a survey of Bristol's politics and society over the whole period-a compact city history in its own right. Chapters 4-8 offer a series of case studies of eighteenth-century riot and unrest, with coherent accounts of popular Jacobitism, and battles over toll roads, food riots, market regulation, and naval impressment. Chapters 9-12 switch to narrative mode to offer an account of Bristol's popular politics and civil disturbances in the age of revolution, from the war of American independence through to the devastating reform riots of 1831.

The book opens with an account of eighteenth-century Bristol as a wealthy city increasingly dominated by a civic and commercial oligarchy whose interaction with participatory politics is 'crucial to understanding the Bristol experience' (93). The working population however had a declining political role: two-thirds of adult males could vote around 1700, but only one in five by 1831 . As the deeply partisan conflicts of the seventeenth century broke down in the early eighteenth century, while the gap rulers and ruled gradually increased, crowd protests with a social edge proliferated. We are in the territory of E. P. Thompson's Whigs and Hunters. There is however no straightforward tale of class conflict: Bristol had a 'crowd that did not play by the rules' (52), and disturbances were 'difficult to accommodate within a narrative of protest, resistance, and progressive politics' (50).

The first thematic chapter, 'Wreckers from Without', has the awkward task of rounding up the city's troublesome elements of the period 1729-34: weavers, colliers, arsonists, and (stretching the boundaries of protest somewhat) 'sodomites'. The chapters on popular Jacobitism and naval impressment provide case studies of Rogers' work on these subjects while those on turnpike riots and food riots are closer to Poole's published interests, but connections are made in all directions and this is more then a set of separate essays. The regional study of Jacobitism has a social and contextual depth lacking in the more usual national 
studies; Rogers argues that Jacobitism was about 'defiance more than insurrection', or 'festive politics that ran to excess'. The chapter on the battles over turnpikes offers a coherent, regionally-grounded account of a hybrid disturbance, nicely weaving in the local politics: both whigs and tories sought to exploit the issue at different stages before uniting against the rioters in 1753. Chapter 7 on food riots and market regulation in Bristol covers the press, the middling sort and local politics as well as the more familiar territory of riots and moral economy, offering a rounded local study over time to compare with John Bohstedt's book-length study of food riots in Manchester and the west country, Riots and Community Politics (1983). Roger's chapter on naval impressment, which take the story right up to 1815 , demonstrates that the people, trading interests and civic leaders together resisted it with considerable success.

The thematic chapters work well, but it is inevitably difficult to maintain a clear narrative across them. The riots of 1734 appear as popular protests against luxury in chapter 4 and as Tory election riots in chapter 5 , while the disturbances of 1753 do duty as turnpike protests in chapter 6 and as food riots in chapter 7. The section on civil politics in relation to the turnpike issue is helpful, but the reader is left flipping between similar material in chapter 3 , on 'Authority, Clientage and Class', and in chapter 5 on 'Popular Jacobitism'. The Bristol Bridge riots of 1793, in which eleven were killed by troops, appear in the chapter on the 1790s with little attempt to connect it back. At times the authors fall back on generalising rhetoric to impose some sort of order: Bristolians, we are told, 'were shaken from their collective reverie' (112), or 'grew wary of impending decline' (116).

The book moves into a more narrative mode with chapter 9 on 'Bristol and the War of American Independence', an episode which ruined the city's American trade and disarranged its civic politics. Pro-American sentiment disrupted the whig/tory duopoly and Edmund Burke served a term as MP for Bristol. The authors however argue convincingly for the importance of a more disruptive and lesser-known figure, Henry Cruger, a radical populist proAmerican merchant who succeeded Burke and actually got himself re-elected while resident in America in 1783. Up to this point the message of the book is that Bristol was strong on resistance of all kinds, but with a unique civic politics which did not break along conventional whig-tory lines, allowing social resistance to gain political traction.

The final three chapters on popular politics follow a more familiar conceptual framework, in which later Hanoverian civic government becomes more remote from an alienated working population. Popular politics, however, fails to respond as expected. Bristol's lack of radicalism in the 1790s is 'anomalous', its profile so low that it was not considered worth repressing. Even the Bristol Bridge riots of 1793 failed to feed political radicalism. A lively chapter on 'Hunt and Liberty' traces the episodic early career of the orator of Peterloo in Bristol: challenging the corporation in 1807, organizing bands of election heavies to drive the tories from the streets in 1812, and getting up a mass petition for reform in 1817. His brand of radical populism, centred around occasional mass meetings, mobilized working-class crowds on a new scale. The 1831 reform riots provide a catastrophic climax worthy of a Zola novel: after mass reform demonstrations the city centre was burnt and looted over three days by out-ofcontrol crowds which the civic authorities dared not challenge - mindful, 
perhaps, of the backlash over the bridge riot and Peterloo. In the end a local military commander, on his own initiative, repeatedly charged and fired upon the rioters, killing uncounted hundreds and putting an end to Bristol's long history of riot. The contrast with the proactive intervention of the Manchester authorities against a peaceful, organized crowd twelve years earlier is striking. The persistence of crowd unrest over radical politics in so socially divided a city makes Bristol from Below a difficult book to sum up and conclude. The authors reject the approach of Thompson and Rudé, with their meta-narrative of a persistence of old-style crowd disturbances alongside modern working-class politics. Instead, they argue that the 'rough and ready logic of crowd actions' (356) can be read as a sort of submerged radicalism. As an example, the looting of Tottenham's shops by its hooded youth in 2011 is somewhat optimistically described as a movement of 'dysfunctional consumers, urged to express their citizenship by the acquisition of consumer goods yet unable to comply with the financial requirements' (326). This sounds rather like Thompson's 'Plebs and Patricians' scenario transplanted forwards a century. It refurbishes a progressive meta-narrative which arguably breaks down in the case of Bristol. Here one would welcome an extension of the more integrated account of civic politics and popular unrest that characterizes the earlier sections. The book is remarkable for its omission of any treatment of the anti-slave trade agitation, with slavery receiving only a single mention after chapter 1 . Yet this was an issue which divided the commercial classes in Britain's leading slave port, and which launched the petitioning habit. Petitioning might also have been given more attention considering it was the main focus of the mass meetings of Hunt's period. Perhaps there was rather more politics going on in the middle, and less on the margins, than appears from this particular selection of episodes.

All in all Bristol from Below is a bold, wide-ranging and important study for all those interested in urban history, in popular protest, and in Britain's eversurprising long eighteenth century.

Robert Poole University of Central Lancashire rpoole@uclan.ac.uk 